\title{
Learning with platform SOLL
}

\author{
ANDREIA M. B. MAGALHÃES
}

Centro de Investigação em Desenvolvimento Humano, Universidade Católica Portuguesa, Porto, Portugal JOSÉ J. MATIAS ALVES

Centro de Investigação em Desenvolvimento Humano, Universidade Católica Portuguesa, Porto, Portugal ANTÓNIO M. V. DE ANDRADE

Centro de Estudos em Gestão e Economia Universidade Católica Portuguesa Porto, Portugal

The technology becomes fundamental for distance learning and the establishment of some social interaction. In this way, the Internet of Things (IoT), emerge with great potential for education because is a network composed of various objects and devices connected to the Internet, allowing the performance of interdisciplinary activities.

Thus, introduces the platform SOLL: Intelligent Objects Linked to Learning which, supported by a set of technologies that collect and store data from a greenhouse, allows dynamic, interactive and interdisciplinary learning and a synchronous or asynchronous assessment.

In this article, the platform's architecture is exposed and from a mixed methodology, student questionnaires and teacher focus group interviews, the data obtained show that this platform respond to the learning community structure, by adopting a different learning model, with exploration and enrichment of educational experiences.

Additional Keywords and Phrases: Education, Technology, Internet of things, Motivation, Learning process

\section{INTRODUTION}

In the perspective of Díaz and Hernández de Frutos [1] that, in a way, inspires the perspective of this study, knowledge also results of a set of network connections in which learning results from the ability to create and cross those connections that emerge in the network from the interaction within a group. However, although these interactions can arise spontaneously, it is something that should be encouraged [2].

Therefore, the technologies "allow the distance learning paradigm to be created" ([3], p. 120) and provide some of the informal social interactions students have at school, based on connectivity, introduced by Siemens in 2004, which is characterized by a network of knowledge and learning, with an emphasis on the use of digital technology to improve and extend online interaction and finding echo in the words of the European Commission [4], in which considers that "digital technologies have an impact on education, training and learning through the development of more flexible learning environments adapted to the needs of a highly mobile society". This will have to evolve into a model based on the "cultivation of skills," ([4], p.98) in which the student needs a more active role, given the high speed of information and knowledge spread in today's society, students will have to maintain lifelong learning, and it is necessary that they be equipped with tools that allow them to evaluate and assimilate new knowledge.

However, new media do not necessarily lead to new pedagogies or new learning [5], as the expository model of content transmission is often maintained, with the novelty of "we can see the teacher from a distance, or watch recordings of your classes, follow your expositions without the special restriction of the classroom and without the temporal restriction of the fixed schedule "([3], p. 120). What is intended is that the teaching-learning process is understood as a construction that involves an active role on the part of the students. It is imperative that they develop the capacity to establish their own goals, to plan and monitor their efforts towards a better academic performance, directing to a certain extent, their learning in the school context [6]. According to Adrião ([4], p.134), the interactivity provided by the digital educational resources can help both in the task of teaching and in the task of learn and encourage and support constructivist pedagogy [7] that, in this way, is more likely to reach all students who wish to participate in the process of knowledge construction and teachers who implement it have further improved technology 
environments [8]. Predicting that the result could be a democratization of education not previously seen [7] and an aid in the fight against school failure.

In this context, "the fundamental paradigm that emerges is teaching in a project environment" ([3], p. 122), which due to its dynamics and interdisciplinary characteristics "captures more attention and involvement from students" ([3], p. 122), in relation to the expository classes.

For this reason, the Internet of Things introduced "a novel paradigm that is rapidly gaining ground in the modern wireless telecommunications scenario" [9]. Some authors argue that it is an unrecedented technology [10]. Is such an innovative technology that its impact on society will be equivalent to that of an Industrial Revolution [11].

The classic Atzory et al [9] states that:

"The basic idea of this concept is the pervasive presence around us of a variety of things or objects - such as Radio-Frequency IDentification (RFID) tags, sensors, actuators, mobile phones, etc. - which, through unique addressing schemes, are able to interact with each other and cooperate with their neighbors to reach common goals."

In this way, Internet of Things "is not a single technology; rather it is an agglomeration of various technologies that work together" (Sethi \& Sarangi, 2017, p. 1) in a interconnection of everyday objects, which are often equipped with ubiquitous intelligence [12] and which exchange ample information between them [13]. This technology will increase the ubiquity of the Internet because it will integrate all objects into an embedded system, which will give rise to a strongly present network of objects communicating with humans or other objects In the same sense. For Gubbi et al. [14], loT is considered as something more user-centered and not restricted to communication protocols, that is, it is the

"Interconnection of detection and actuation devices, providing the ability to share information across platforms through a unified framework, developing a common operational framework to enable innovative applications. This is achieved by ubiquitous detection, data analysis, and information representation with cloud computing as a unifying structure "([14], p.1647).

In other words, it is a technology that allows, through sensors, to connect objects with the Internet so that information about the environment or activity can be obtained and that will provide feedback and control [11].

According to Aldowah et. al [15] "new forms of information exchange lay the foundation for more interactive and personalized learning" and real-time data "are useful for analysing actions, interactions, preference trends and changes in student skill levels" [15]. The teacher remains "essential for guiding students to and through learning objects" and "must also take students away from the variety of disconnected experiences to develop meaning and assimilate their new knowledge, skills and emotions" ([16], p. 35).

This technology, according to Area [17], should mobilize and integrate pedagogical dimensions, such as: informational, resources and materials, texts, videos; practice, experience and learning activities, individual and group; communicative, social interaction between students and teacher and dimension tutorial and assessment, monitoring and assessment of learning by the teacher.

As for the pedagogy to be used, according to Mortimer [18], it is any conscious activity of a person designed to improve the learning of another. Thus, the teacher should use several pedagogical models to focus the discussion on the essential topics, acting as a guide and a facilitator of learning [19]. The teacher must help to contextualize, to expand the universe reached by the students and to help the 
discovery of new meanings [20]. In a social dimension, the teacher should act as a discussion advisor [19] motivating participation [21] and facilitating interactivity in the learning community [22].

For the teacher to guide students towards meaningful learning and in a dynamic learning environment Garrison \& Aderson [23] establishes a set of indicators of the presence of teaching, which includes the cognitive and social presence and which is shown in Table 1, cited by Monteiro \& Moreira ([24], p. 41) withdrawn and adapted from Garrison \& Aderson [25].

Table 1: Indicators of the presence of teaching cited by Monteiro \& Moreira [24] withdraw and adapted by Garrison \& Anderson [25]

\begin{tabular}{|c|c|c|c|}
\hline \multirow{20}{*}{ 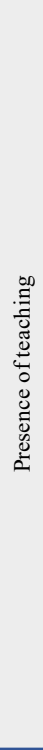 } & \multirow{4}{*}{$\begin{array}{c}\text { Design and } \\
\text { organization }\end{array}$} & \multirow{3}{*}{$\begin{array}{l}\text { Cognitive } \\
\text { presence }\end{array}$} & Organize and limit the curriculum, select activities \\
\hline & & & Set times \\
\hline & & & Design assessment tools \\
\hline & & Social presence & $\begin{array}{l}\text { Establish an environment of trust, hospitality, warmth, control, accomplishment, } \\
\text { sharing and dialogue }\end{array}$ \\
\hline & \multirow{4}{*}{$\begin{array}{c}\text { Speech } \\
\text { facilitation }\end{array}$} & \multirow{3}{*}{$\begin{array}{l}\text { Cognitive } \\
\text { presence }\end{array}$} & Focus and moderate discussions \\
\hline & & & Asking stimulating questions \\
\hline & & & Questioner, promote reflection \\
\hline & & Social presence & Motivate students to participate \\
\hline & \multirow{12}{*}{$\begin{array}{c}\text { Direct } \\
\text { instruction }\end{array}$} & \multirow{7}{*}{$\begin{array}{l}\text { Cognitive } \\
\text { presence }\end{array}$} & Offer different ideas and perspectives for analys is and discussion \\
\hline & & & Respond directly to questions and make comments more developed \\
\hline & & & Recognize the uncertainty where it existed \\
\hline & & & Make connections between ideas \\
\hline & & & Build structures \\
\hline & & & Summarize discussions and conduct learning \\
\hline & & & Provide for closure and foreshadow further study \\
\hline & & \multirow{5}{*}{ Social Presence } & Shaping the discussion, but not dominating it \\
\hline & & & Give feedback with respect \\
\hline & & & Be constructive with correction comments \\
\hline & & & Be open to negotiation and justifications \\
\hline & & & Deal with conflict quickly and privately \\
\hline
\end{tabular}

Thus, opportunity arises for the development of new learning skills, recognized in the Profile of Students Leaving Mandatory Schooling [26], approved by the Order 6478/2017, July 26, constitutes a common matrix for all schools and educational offers within the scope of compulsory education, namely at the curriculum, to help students develop skills in order to become successful students, confident individuals and creative, as well as active and informed citizens [27].

In this sense, the use of technology-rich environments that replicate the interdisciplinarity of the real world is a determining factor and the Internet of Things is an excellent ally, to motivate and involve students in learning, particularly the young ones due to the lower capacity for self-regulation.

In order to operationalize the above, the SOLL platform: Smart Objects Linked to Learning emerged, which is supported by a set of technologies that collect and store real data for later interdisciplinary analysis.

\subsection{LEARNING ONLINE PLATFORM - SOLL}

In order to take advantage of technology to create for students special learning conditions "so that, they are able to critically select and seek the knowledge they wish to acquire, and integrate them into the set of knowledge that they already have and are capable of conducting a practice based on them " ([28], p.69), the SOLL: Smart Objects Linked to Learning [29] project was created, which is based on the construction of a greenhouse, monitored by sensors that, through the Internet of Things, transmit real data in real time and constantly updated for the SOLL platform. From this, the students, 
aged between 12 and 15 years, perform a set of activities which fulfil the Essential Learning of the subjects of the 3rd Cycle of Basic Education, and intervene on the environment, acquiring new values. From the interaction between the different project targets, as shown in figure 1, all the work is developed by students in an integrated and interdisciplinary way.

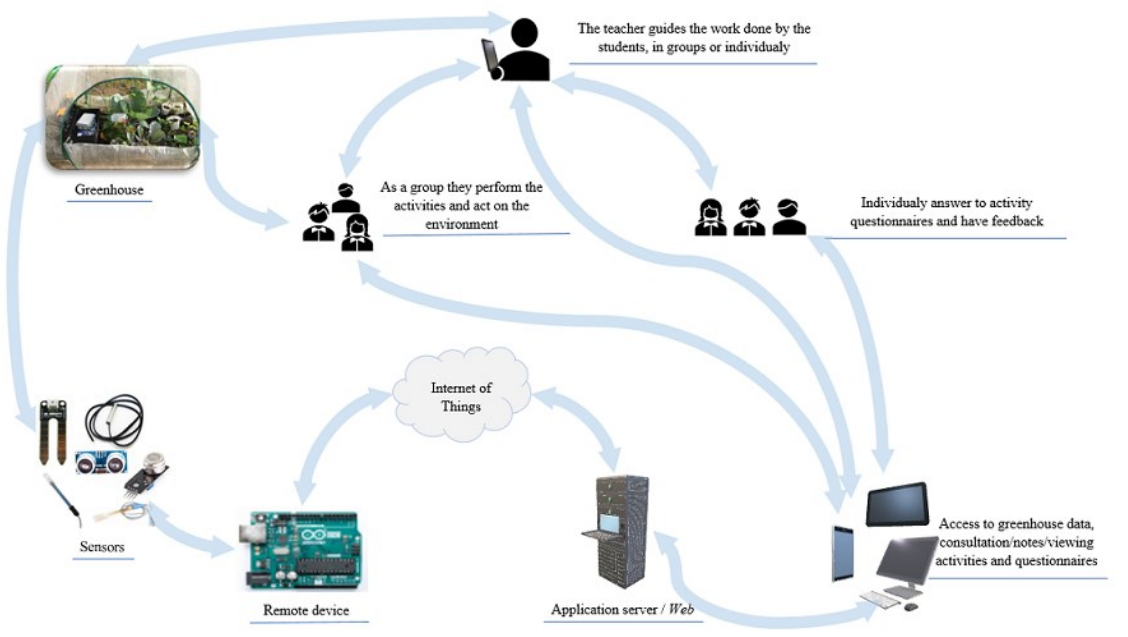

Figure 1: Interaction between the different targets of the SOLL project, prepared by the authors

The online learning platform, www.soll.pt, is supported by a set of technologies that collect and store real data. The figure 2 shows a map of the SOLL learning platform. To access this learning platform - SOLL, both teachers and students need to do an authentication. For this, they require a user and a password that will be sent by the administrator of the learning platform.

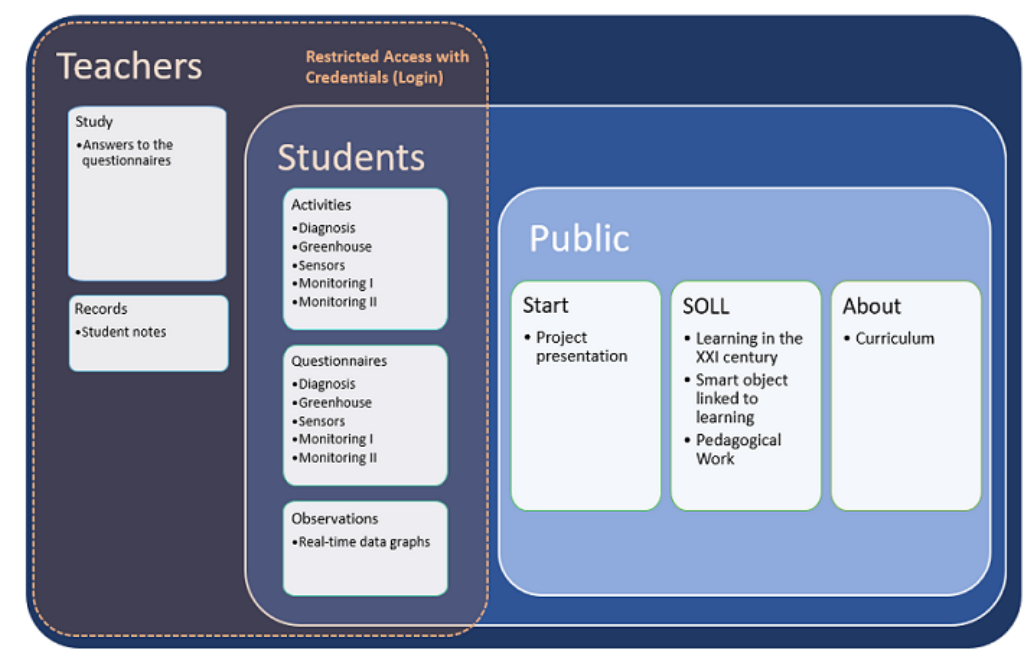

Figure 2: Map of the SOLL learning platform, elaborated by the authors

As can be seen from the diagram, students have access only to activities, questionnaires and observations of actual data from the greenhouse. From this platform of learning, students are offered 
some activities, which comply with the Essential Learning of the respective disciplines and encourages action on the environment.

Each activity has associated a notepad, useful links for information research, access to tools that work synchronously and asynchronously, for the presentation of the work done and informational documents.

After the activity is carried out, students will be asked to carry out a questionnaire about it and, at the end of it, a feedback on the evaluation and correction of the incorrect answers will. In this way, as you wish, "the assessment is continuous and systematic in the service of learning, and provides the teacher, the student, (...) with information on the development of the work, the quality of the learning done and the ways to improve it" ([30], p. 3790-(4)) and "the information obtained as a result of the evaluation also allows the revision of the teaching and learning process" ([30], p. 3790-(4)).

With this interdisciplinary resource, students achieve what is required in the Student Profile when Exit Compulsory Schooling, in which "Areas of Competence add competences understood as complex combinations of knowledge, skills and attitudes that allow effective human action in diverse contexts. They are of diverse nature: cognitive and metacognitive, social and emotional, physical and practical. It is important to emphasize that competences involve knowledge (factual, concetual, procedural and metacognitive), cognitive and psychomotor skills, attitudes associated with social and organizational skills, and ethical values. ([31], p.9).

The teachers have access to a management system of student activity on the platform and, the same learning platform, allows teachers to monitor, in real time, the activities carried out by the students through the observation of the notepad, and the answers to the questionnaires.

In this way, the teacher has a sense of the students' performance and/or difficulties and can provide a more personalized teaching, since it allows the real time verification of the individual or group work.

\section{RESULTS}

Regarding the students' data that compare the impact on motivation, Graphic 1, between the diagnostic survey before the activity (pre-test) and the final survey after the activity (post-test), we choose the Sign Test. This test is a nonparametric alternative to the t-test for paired samples, which "allows to analyse differences between two pretest and posttest conditions in the same group of subjects" ([46] , p. 478), which should be as similar as possible in aspects that may affect their responses in ordinal or higher level variables. For $\alpha=0.05$, the hypotheses for the nonparametric statistical test, sign test, are: H0: There are no differences regarding the topic between pre-test and post-test, $\left(X_{i}=Y_{i} ; p=0,50\right)$ e $H_{1}$ : There was an improvement in the topic at the end of the activity, $\left(Y_{i}>X_{i}, p>0,50\right.$, unilateral test). 


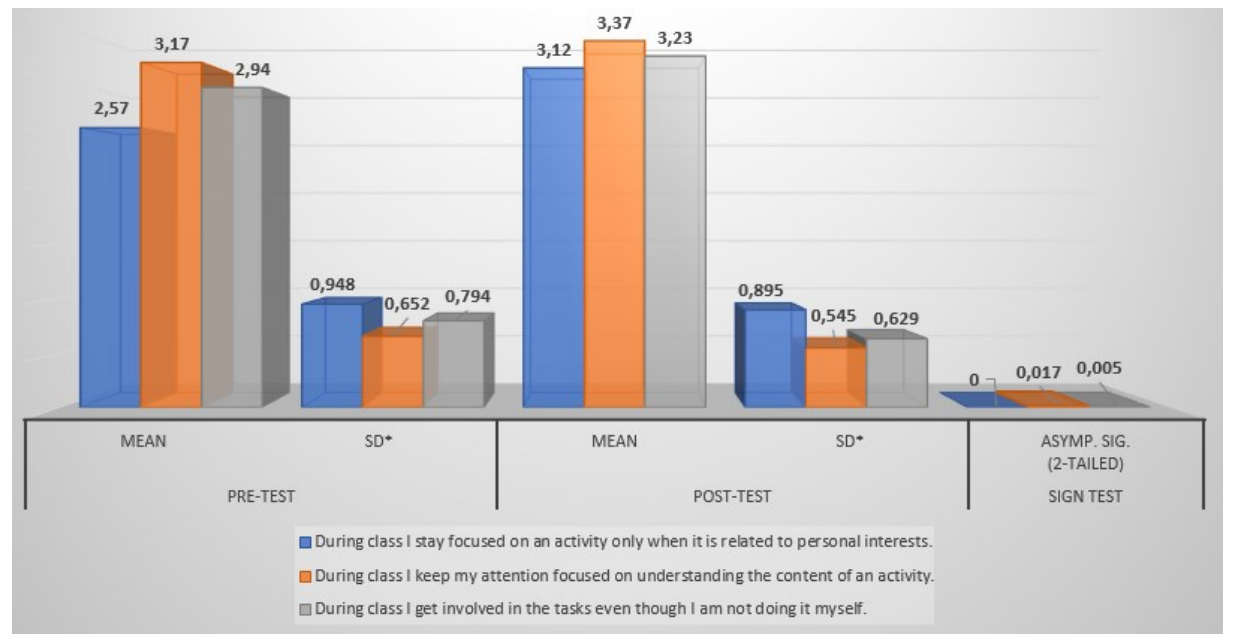

Graphic 1: Student results regarding the impact on motivation between the diagnostic survey before the activity (pretest) and the final survey the activity (pos-test)

The same study was done for the learning process category, as shown in graph 2 .

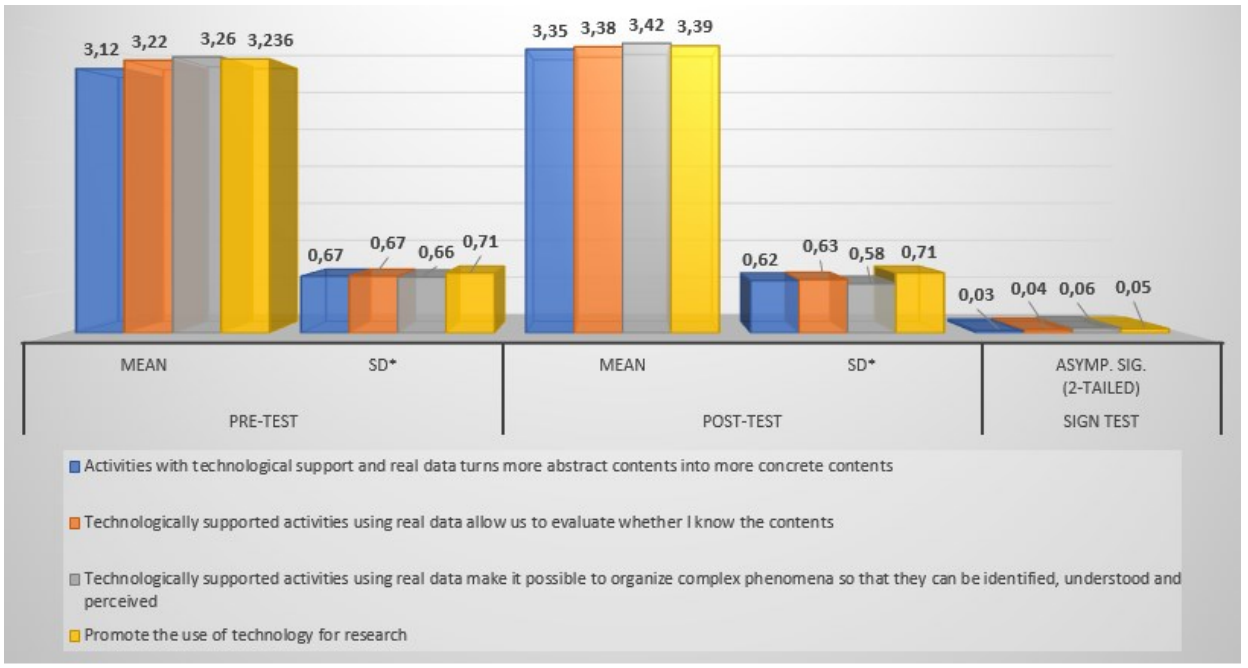

Graphic 2: Student results regarding the impact on learning process between the diagnostic survey before the activity (pre-test) and the final survey after activity (pos-test)

From the focus group of teachers, some opinions were collected regarding the categories motivation and learning process that are presented in the table 2 .

Table 2: Teachers' opinions regarding the motivation and learning process

"they liked ... is, motivated ... Yes, I agree"

"Yes... it is . another impact ... here it is not quite that but when it is applied... Reality makes Motivation more sense, isn't it ..."

"yes, they liked ... were always asking when the next activity was ..."

"they even wanted to know more ..." 


"they feel closer to what they like, which is their interests ... at least at first, it's not ... later
sometimes ... when it comes to the content part ... but it's more appealing to them, is a
different way of exploring certain subjects ... in a much more interesting way ..."
"Often students have to be guided. It is not... also sometimes do not know very well
distinguish the essential of the accessory... have to be very oriented and even in research ..."
"it promote interdisciplinarity ... and we could even use this in the future to develop more
Learning aspects"
process "we can easily join here $4 / 5$ areas"
deep down it forces them to interpret, to be critical of the data they are receiving ... so it ends
up building, consolidating and structuring knowledge.
"there is no better construction of knowledge that is not like that ... I think it's the best way ...
even is they realize that ultimately all areas of knowledge are bound together ... and that
complement ... in terms of knowledge..."

\section{DISCUSSION}

In this platform emerges as an asset to motivate students to learn and involve them in the learning process becomes useful the exploration and enrichment of learning interdisciplinar through the realization of dynamic, contextualized and real activities that provide the development of various skills, "useful for analysing actions, interactions, preference trends, and changes in student skill levels," as refereed by Aldowah et. al [15]. So the teacher can take advantage for to "plan and structure the educational process in an open and flexible way, allowing diversified approaches, where resources and dynamic, current and motivating teaching materials are inserted, using for this an interactive and cooperative methodology, placing at the service of its teaching several communication channels" Goulão \& Henriques ([51], p.28) and enjoy this technology to accompany, motivate, dialogue, be a leader and mediator, fostering and mediating a positive human interaction".

This platform, find echo in the current directives recommended by the OECD [4], when responding to current learning since it brings numerous benefits to the development of children, especially in the construction of their identity, leading the child to their autonomy and acquisition of new knowledge, enabling their effective development knowing how to use personal resources in the face of the adversities that will face in their life [34]. In this way, the teacher can accompany, motivate, dialogue, be a leader and mediator, fostering and mediating a positive human interaction" ([36], p. 28 e 29).

In short, the SOLL platform demonstrates robustness for allow the interdisciplinary development of the learning process of the 3rd cycle students and an is excellent ally, to motivate and involve students in learning, particularly the most young ones due to the lower capacity for self-regulation.

\section{CONCLUSION}

In this platform emerges as an asset to motivate students to learn and involve them in the learning process becomes useful the exploration and enrichment of learning interdisciplinar through the realization of dynamic, contextualized and real activities that provide the development of various skills, "useful for analysing actions, interactions, preference trends, and changes in student skill levels," as refereed by Aldowah et. al [15]. So the teacher can take advantage for to "plan and structure the educational process in an open and flexible way, allowing diversified approaches, where resources and dynamic, current and motivating teaching materials are inserted, using for this an interactive and cooperative methodology, placing at the service of its teaching several communication channels" Goulão \& Henriques ([51], p.28) 
and enjoy this technology to accompany, motivate, dialogue, be a leader and mediator, fostering and mediating a positive human interaction".

This platform, find echo in the current directives recommended by the OECD [4], when responding to current learning since it brings numerous benefits to the development of children, especially in the construction of their identity, leading the child to their autonomy and acquisition of new knowledge, enabling their effective development knowing how to use personal resources in the face of the adversities that will face in their life [34]. In this way, the teacher can accompany, motivate, dialogue, be a leader and mediator, fostering and mediating a positive human interaction" ([36], p. 28 e 29).

In short, the SOLL platform demonstrates robustness for allow the interdisciplinary development of the learning process of the 3rd cycle students and an is excellent ally, to motivate and involve students in learning, particularly the most young ones due to the lower capacity for self-regulation.

\section{REFERENCES}

[1] T. H. Díaz, J. A., \& de Frutos, "Connectivism in the Network Society. The Coming of Social Capital Knowledge. Tendencias Sociales.," Rev. Sociol. 1(2018), 21-37, 2018.

[2] O. C. Cabrero, R. S., \& Román, "Psychopedagogical Predecessors of Connectivism as a New Paradigm of Learning," Int. J. Educ. Excell. 4(2), 29-45. Retrieved from http//revistas.uned.es/index.php/Tendencias/artic/e/view/21358/17565, 2018.

[3] R. Carapuça, "Revolução Digital - Quando quase Tudo É Possível," Fundação Luso-Americana para o Desenvolv., 2018.

[4] D. Adrião, "Um novo paradigma educativo para Portugal no século XXI," Educanology, 2018.

[5] and B. C. Kalantzis, Mary, "Conceptualizing e-Learning.," e-Learning Ecol. Ed. by Bill Cope Mary Kalantzis, 1-45. New York Routledge., 2017.

[6] L. Souza, "Estratégias de aprendizagem e fatores motivacionais relacionados.," Educ. rev., Curitiba , n. 36, 2010.

[7] L. D. Reid-Martinez, K., \& Grooms, "Online Learning Propelled by Constructivism.," Encycl. Inf. Sci. Technol. Fourth Ed. (pp. 2588-2598). IGI Glob., 2018

[8] A. Sultan, W., Woods, P., \& Koo, "A constructivist approach for digital learning: Malaysian schools case study.," Educ. Technol. Soc. 14(4), 149-163., 2011.

[9] L. Atzori, A. lera, and G. Morabito, “The Internet of Things : A survey," Comput. Networks, vol. 54, no. 15, pp. 2787-2805, 2010.

[10] R. \& B. Kranenburg, "The Internet of Things," Pap. 1st Belin Symp. Internet Soc. Oct. 25-27, 2012.

[11] H. M. O'Brien, “The Internet of Things.," J. Internet Law, 19(12), 1-20., 2016.

[12] W. \& V. Xia, Yang, "Internet of Things.," Int. J. Comun. Syst. Vol. 25, Issue 9 Sept. 2012 Pages 1101-1102., 2012.

[13] T. Singer, "Tudo conectado: conceitos e representações da internet das coisas.," Simpósio em Tecnol. Digit. e Sociabilidade - Práticas Interacionais em Rede., 2012.

[14] M. Gubbi, J., Buyya, R., Marusic, S., \& Palaniswami, "Internet of Things (IoT): A vision, architectural elements, and future directions.," Futur. Gener. Comput. Syst. 29(7), 1645-1660., 2013.

[15] I. Aldowah, H., Ghazal, S. Rehman, S. Umar, "Internet of Things in Higher Education: A Study on Future Learning," J. Phys. Conf. Ser., 2017.

[16] R. Slimp, M. \& Bartels, "How the Internet of Things is Changing ourColleges, our Classroom, and our Students," Foreword by Fred Lokken. Br. Libr. Publ. Inf. Available, 2019.

[17] J. Area, M \& Adell, "eLearning Enseñar y aprender en espacios virtuales.," J. Pablos Tecnol. Educ. La Form. del Profr. en la era Intenet (pp.391-424). Malaga Aljibe, 2009.

[18] E. Mortimer, "Microgenetic analysis and the dynamic of explanations in science classroom.," Pap. Present. I/ Conf. Eur. Sci. Educ. Res. Assoc. Kiel., 1999.

[19] M. Berge, Z., e Collins, "Facilitating Interaction in Computer Mediated Online Courses.," Backgr. Pap. Present. FSU/AECT Distance Educ. Conf. Tallahasee FL., 2000.

[20] J. Moran, "A pedagogia e a didatica da educacao Online. Em Educacao, Aprendizagem e Tecnologia. Um paradigma para professores do seculo XXI.," Edicoes Silab., 2005.

[21] B. Davis, "Tools for Teaching.," Publ. Jossey-Bass, 1993.

[22] J. Schofield, M., Sackville, A., e Davey, "Designing for unique Online Learning Contexts: The Aligment of Purpose, Audience, 
and Form of Interactivity. Em Managing Learning in Virtual Settings. the Role of Context.," Inf. Sci. Publ., 2006.

[23] T. Garrison, D; Anderson, "El e-learning en el siglo XXI. Investigación e prática.," Barcelona Editor. UOC, 2005.

[24] J. Monteiro, A. \& Moreira, "O Blended Learning e a integração de sujeitos, tecnologias, modelos e estratégias em ensinoaprendizagem," Blended Learn. em Context. Educ. - Perspetivas teóricas e práticas Investig. Monteiro, A.; Moreira, J., Almaida, A.; Lencastre, J.; FACTO Ed. $2^{a}$ Edição, 2013.

[25] T. Garrison, D. R. \& Anderson, "E-Learning in the 21st Century.," London: RoutledgeFalmer, 2003.

[26] Despacho and 26 de julho n. ${ }^{\circ}$ 6478/2017, "Perfil dos Alunos à Saída da Escolaridade Obrigatória," Ministério da Educ. Direção Geral da Educ., 2017.

[27] K. Beghetto, J. Ronald, "Nurturing Creativity in the Classroom," Ed., 2nd New York Cambridge Univ. Press., 2017.

[28] H. Costa, "Inovação Pedagógica: A tecnologia ao serviço da educação," Chiado Ed., 2014.

[29] A. A., Magalhães; A., Andrade; J., "SOLL: Smart Objects Linked to Learning - Educational platform with the Internet of Thingsitle," Em 2019, 14ª Conferência Ibérica Sist. e Tecnol. Informação (CISTI), IEEE., 2019.

[30] S. I. de 2018-08-03 Diário da República n. ${ }^{\circ}$ 149/2018, $1^{\circ}$ Suplemento, "Decreto-Lei n. ${ }^{\circ}$ 55/2018, de 6 de julho."

[31] S. Martins, G., Gomes, C., Brocardo, J., Pedroso, J., Carrillo, J., Silva, L., Encarnação, M., Horta, M., Calçada, M., Nery, R., Rodrigues, "Perfil dos Alunos à Saída da Escolaridade Obrigatória," Ministério da Educ. - Direção Geral da Educ., 2017.

[32] J. Pestana, M.; Gageiro, "Análise de Dados para Ciências Sociais - A Complementaridade do SPSS," Edições Silabo, vol. 5a Edução, 2008. 